\title{
eCommons@AKU
}

Book Chapters

January 2014

\section{The continuing evolution of the research doctorate}

\author{
Bianca L. Bernstein \\ Arizona State University \\ Barbara Evans \\ University of British Columbia \\ Jeannette Fyffe \\ La Trobe University \\ Nelofer Halai \\ Aga Khan University, Institute for Educational Development, Karachi \\ Fred L. Hall \\ University of Calgary \\ See next page for additional authors
}

Follow this and additional works at: http://ecommons.aku.edu/book_chapters

Part of the Educational Assessment, Evaluation, and Research Commons, Higher Education Commons, Higher Education Administration Commons, Higher Education and Teaching Commons, Other Educational Administration and Supervision Commons, and the Other Teacher Education and Professional Development Commons

\section{Recommended Citation}

Bernstein, B. L., Evans, B., Fyffe, J., Halai, N., Hall, F. L., Marsh, H., \& Jensen, H. S. (2014). The continuing evolution of the research doctorate. In M. Nerad \& B. Evans (Eds.), Globalization and its impacts on the quality of $\mathrm{PhD}$ education: Forces and forms in doctoral education worldwide (pp. 5-30). Rotterdam: Sense Publishers. 
Authors

Bianca L. Bernstein, Barbara Evans, Jeannette Fyffe, Nelofer Halai, Fred L. Hall, Mukobe Siggaard Jensen, Kazim Papeiva, and Suzanne Ortega 


\section{BIANCA L. BERNSTEIN, BARBARA EVANS, JEANNETTE FYFFE, NELOFER HALAI, FRED L. HALL, HANS SIGGAARD JENSEN, HELENE MARSH \& SUZANNE ORTEGA}

\section{THE CONTINUING EVOLUTION OF THE RESEARCH DOCTORATE}

\section{OVERVIEW}

In this chapter, we offer a synthesis of international perspectives on the nature of the $\mathrm{PhD}$, its contribution to original research, and the competencies and outcomes now expected of those completing a $\mathrm{PhD} .{ }^{1}$ As a resource for all doctoral programs, this synthesis can provide a basis for (1) improving the quality of outcomes for all $\mathrm{PhD}$ students, (2) explicitly differentiating doctoral programs to promote understanding and diversity within a broadly accepted framework, (3) facilitating discussion among universities and governmental agencies about quality assurance and funding, and (4) promoting mobility among $\mathrm{PhD}$ holders by clarifying commonalities in the degree across countries and educational systems.

We begin with a discussion of what constitutes a $\mathrm{PhD}$, with particular emphasis on the international nature and aims of today's research doctoral programs. Our emphasis throughout the chapter is on the emerging articulation of the desired outcomes for research doctoral education, including the increasing agreement that $\mathrm{PhD}$ training should include the development of particular skills that can be transferred from academic to other professional settings, and from one professional setting to another-skills that enhance graduates' employability, their ability to manage their own careers, and their sense of responsibility for making contributions to society. We also consider current forces and pressures affecting doctoral education, and we conclude with a discussion of issues and directions that merit additional attention and further research.

\section{INTRODUCTION: WHAT IS A DOCTORAL DEGREE?}

Research doctoral graduates represent an institution's finest students. They are also the ones most likely to become tomorrow's world leaders. As the most prestigiousand the most international — of academic degrees, the $\mathrm{PhD}$ prepares leaders for careers in academia and research but also and increasingly for a broad range of careers in other sectors (including business, industry, the nonprofit sector, and government) and across international settings. 


\section{B. L. BERNSTEIN ET AL.}

Given this international context, to what extent is there an international understanding regarding what a $\mathrm{PhD}$ encompasses or should encompass? An examination of research and policy statements from Europe, from the United States, and from Canada and Australia reveals three broad commonalities expected of $\mathrm{PhD}$ programs:

1. There is clear international agreement that the $\mathrm{PhD}$ should contribute to knowledge through original research.

2. $\mathrm{PhD}$ graduates are expected to have substantial knowledge in their areas.

3. There is increasing agreement that $\mathrm{PhD}$ training should include development of transferable skills and competencies.

Doctoral Programmes for European Knowledge Society 2004-2005, a European University Association-EUA/Socrates-funded project involving forty-eight universities from twenty-two European countries, concluded that closer international collaboration between and among research institutions would require consensus across a set of ten basic principles, known as the Salzburg Principles. These principles outline a set of ideals that are relevant to the improvement and quality assurance of doctoral programs at universities in every country (European University Association, 2005):

1. The core component of doctoral training is the advancement of knowledge through original research. However, doctoral training must also meet the demands of an employment market wider than academia.

2. Universities must assume responsibility for ensuring their doctoral programmes are designed to meet new challenges and include appropriate professional career development opportunities.

3. Diversity of doctoral programs, including joint doctorates, is a strength that must be underpinned by sound quality and practice.

4. Doctoral students should be recognized as early-career researchers who are making key contributions to knowledge creation.

5. Supervision and assessment are crucial, and should be based on transparent contractual understandings between students, supervisors, and institutions.

6. Doctoral programmes should seek to achieve critical mass, ranging from graduate schools in major universities to international, national, and regional collaborations between universities.

7. Doctoral programmes should be completed within three to four years.

8. Doctoral programmes should include innovative structures to meet the challenge of interdisciplinary training and the development of transferable skills.

9. Doctoral programmes should increase mobility, offering geographic as well as interdisciplinary and intersectoral mobility and international collaboration within an integrated framework of cooperation.

10. Doctoral programmes should ensure appropriate funding. 


\section{History of the PhD}

The nature and the form of research doctoral education have changed fundamentally since medieval times (see table 1.1, which, as we recognize, represents a history of European doctoral education). The tutors of earlier centuries have been replaced by multiple supervisors, programs of study, and committees of examiners. What was once a small number of research disciplines has now grown to an array of almost eighty fields in which research doctorates are awarded. Likewise, what was once a small group of privileged apprentices in a handful of elite universities has now been replaced by tens of thousands of doctoral students in hundreds of universities. Moreover, borders and barriers have been supplanted by global landscapes, simulations, collaborations, study abroad, and instant communication. As a result, research doctorates are increasingly offered by institutions all over the world, not just by research universities in Europe and North America. Doctorates are also offered jointly by collaborating institutions in different countries, by institutions operating outside their home countries, and through distance education. The graduates of today's research doctoral programs work in roles and settings that were unimaginable in earlier times.

Table 1.1. History of Doctoral Education

\begin{tabular}{|c|c|c|c|}
\hline Period & $\begin{array}{l}\text { Purposes of Doctoral } \\
\text { Education }\end{array}$ & Subjects Studied & Type of Examination \\
\hline $\begin{array}{l}\text { Medieval Europe } \\
(1200-1535)\end{array}$ & $\begin{array}{l}\text { To foster } \\
\text { communities of } \\
\text { scholars teaching and } \\
\text { writing textbooks }\end{array}$ & $\begin{array}{l}\text { Medicine, law, } \\
\text { theology }\end{array}$ & $\begin{array}{l}\text { Oral (teacher wrote } \\
\text { thesis, student had to } \\
\text { defend or oppose it) }\end{array}$ \\
\hline $\begin{array}{l}\text { Reformation Europe } \\
(1535-1750)\end{array}$ & $\begin{array}{l}\text { To train priests and } \\
\text { church administrators }\end{array}$ & Theology, law & $\begin{array}{l}\text { Examination by } \\
\text { board of professors } \\
\text { in all subjects (no } \\
\text { specialization) }\end{array}$ \\
\hline $\begin{array}{l}\text { Enlightenment } \\
\text { Europe (1750-1865) }\end{array}$ & $\begin{array}{l}\text { To create new } \\
\text { knowledge; to train } \\
\text { future professors }\end{array}$ & $\begin{array}{l}\text { Philosophy, } \\
\text { humanities, natural } \\
\text { sciences }\end{array}$ & $\begin{array}{l}\text { Written (student } \\
\text { wrote thesis, } \\
\text { faculty took role of } \\
\text { opponents) }\end{array}$ \\
\hline $\begin{array}{l}\text { Era of the modern } \\
\text { research university } \\
\text { (1865-present) }\end{array}$ & $\begin{array}{l}\text { To foster settings } \\
\text { for research and } \\
\text { research-based } \\
\text { training }\end{array}$ & $\begin{array}{l}\text { The subject matter of } \\
\text { most academic fields } \\
\text { as well as that of } \\
\text { professional schools }\end{array}$ & $\begin{array}{l}\text { Written and oral } \\
\text { (student writes and } \\
\text { defends dissertation) }\end{array}$ \\
\hline
\end{tabular}




\section{B. L. BERNSTEIN ET AL.}

\section{The International Character of Today's PhD}

As the $\mathrm{PhD}$ spread around the globe, it developed differently in each country, taking on the character of the institutions that offered it and also responding to and reflecting the needs of particular societies. The degree as it is known today is not simply the product of an unbroken line of teaching and learning that stretches all the way back to the medieval university. Rather, it has been shaped and driven by disjunctive intellectual and technological developments and economic realities.

The career paths for individual PhD graduates have also expanded, and the global need for demonstrated leadership has risen with that expansion. $\mathrm{PhD}$ graduates are expected more and more to make effective contributions on the global stage. Regardless of where someone earns the doctoral degree, countries look to their most educated and capable citizens to bring their knowledge, their ability to innovate, and their best practices back home and then apply them to the most pressing economic, technological, and social concerns of the day and to those anticipated for the future. A World Bank report puts this issue succinctly: "Participation in the knowledge economy requires a new set of human skills. People need higher qualifications and [the capacity for] greater intellectual independence .... Without improved human capital, countries will inevitably fall behind and experience intellectual and economic marginalization and isolation" (Task Force on Higher Education and Society, 2000, p. 22).

The majority of doctoral students, wherever they come from around the world, attend universities in industrialized nations that are able to offer specialized and differentiated doctoral degree programs, multiple career opportunities, and high standards of living. In the developing nations, where half the world's students live, the number of available places in universities cannot keep pace with the demand for graduate education or with quality benchmarks. Therefore, the brightest students in the developing nations must travel to foreign universities to obtain highquality education, and the governments of many developing countries encourage bright students to go abroad, often using scholarships as inducements, as part of a general policy of capacity building so that they can plug themselves in to the latest thinking in the West. Nevertheless, according to an article in The Economist ("Wandering Scholars," 2005), "few highly skilled migrants cut their links with their home countries completely. Most keep in touch, sending remittances (and, if they are successful, venture capital), circulating ideas and connections, and even returning home as successful entrepreneurs. . . . [A] growing number of expatriate businessmen invest back home."

As a result, the rising competition for talented students and globally literate graduates is contributing to a new economy of international student flow. It is estimated that by 2025, eight million students will be studying outside their home countries, and about 80 percent of them will be from developing countries (Altbach, 2004). The urgent need to expand human capital and to advance economic development in developing countries, along with the revenue advantages of exchange, are underscoring the critical role of graduate education for the global stage. 
PhD graduates are sought worldwide for their ability to create and convey knowledge, provide leadership, drive the process of nation building, and foster innovation and prosperity. In fact, because the $\mathrm{PhD}$ is the most international of degrees, institutional practices associated with the evaluation of $\mathrm{PhD}$ students often reflect the anticipated benefits of multinational perspectives. For example, in many countries outside the United States, international experts in a field often conduct an external examination of the product of the work (the thesis or dissertation). ${ }^{2}$ The increasingly collaborative, international nature of research and knowledge production is also noteworthy. Supervision of doctoral research is crossing national boundaries and may include international joint (cotutelle) degrees. Notable as well is the new transnationalism (Altbach, 2004), whereby one country's educational institutions operate in another country or through distance education.

\section{ESTABLISHING EXPECTATIONS FOR DOCTORAL APPLICANTS AND GRADUATES}

In view of all these developments, what is expected of $\mathrm{PhD}$ students and graduates in different educational systems? With respect to both applicants and graduates, originality of the contribution to research or professional practice, disciplinary knowledge and skills, and professional and personal competencies are all considerations.

\section{Competencies Expected of Research PhD Applicants}

A university typically expects an applicant for a research doctorate to demonstrate advanced knowledge of the particular discipline as well as the capacity to undertake significant research in the intended field. Most universities also expect doctoral applicants to be proficient readers and writers of English. Institutions stipulate their expectations in order to increase the likelihood that each accepted candidate will have the background needed to complete a high-quality doctorate in a timely manner. In tacit acknowledgment of the limited predictive capacity of entry qualifications, research doctoral programs typically require additional education and assessment of candidates in the initial year(s) of a program. ${ }^{3}$ In any case, there is much variation across countries in how individual candidates' entry qualifications are assessed. ${ }^{4} \mathrm{We}$ have not attempted here to provide a quantitative survey of national practices but only to illustrate the diversity of approaches.

\section{Advanced Knowledge of the Discipline}

Universities generally use applicants' tertiary qualifications as a measure of advanced disciplinary knowledge. Thus, for entry into a research doctoral program, the university typically expects either a master's degree (by research or coursework) in the respective discipline or a bachelor's degree with an appropriate disciplinary major along with high grades or honors. The number of years of university education 


\section{B. L. BERNSTEIN ET AL.}

considered necessary to reach the expected level of knowledge for entry varies by country, from about three to six years; this variation reflects the nature of the preceding secondary and undergraduate education in the particular country.

Research doctoral candidates in Canada, China, the Czech Republic, New Zealand, and South Asian countries like Pakistan typically have a master's degree, as candidates often do in the United States as well. In some European countries, access to doctoral studies is regulated by law and requires a master's degree as the entry point (this is the case, for example, in Hungary, France, and the Republic of Lithuania; see European University Association, 2007). In most European countries, however, access is more open, and there is a plurality of pathways.

Many universities do not explicitly identify the master's degree as the main requirement for access, although that degree does remain the most common route. In the United Kingdom, entry into a research doctoral program is possible after a three-year honors bachelor's degree or a master's degree, whereas entry is possible in Australia by way of a number of routes, including a three- or four-year bachelor's degree plus a one-year honors program (which typically has a significant research component) or a master's degree by either research or coursework.

The European University Association (2006) developed the following statement in relation to entry qualifications for doctoral programs:

In a fast-changing environment, it is essential to maintain flexibility in admissions to doctoral programmes, and full institutional autonomy: diversity of institutional missions and context, and the growing importance of lifelong learning, mean that there are good reasons for different entry requirements in institutions and programmes[,] provided fairness, transparency and objectivity [are] ensured .... The Bologna commitment that the second cycle [master's degree programs] gives access (meaning the right to be considered for admission) to the third cycle [doctoral programs] should be maintained, but access to the third cycle should not be restricted to this route.

It should also be recognized that some students, because of their maturity, their work experience, or other factors, exhibit core competencies at the beginning of their doctoral studies. In addition-for at least some research doctoral programs, particularly professional doctorates - universities may also recognize substantial professional experience as an appropriate additional or partial substitute requirement for entry.

\section{Capacity for Research}

Measuring a research doctoral applicant's capacity to undertake significant research in the proposed field can be more of a challenge than assessing the applicant's academic knowledge. Previous research experience remains among the best predictors of success at the doctoral level. For that reason, many countries have made heavy investments in expanding research opportunities for undergraduates, and graduate programs increasingly use such experience as a key criterion for 
admission to doctoral education. In other countries, opportunities are very limited for an undergraduate or a master's degree candidate to undertake significant research.

There are also significant differences among countries with respect to doctoral candidates' exposure to critical thinking and independent learning, two competencies that are essential indicators of research capacity. These differences, like those related to the required number of years of prior education, reflect the nature of the particular country's system of secondary and undergraduate education. For example, some applicants, even at the graduate level, have been educated in systems that allow students to rely on rote learning. These students have not been encouraged to challenge teachers or book-based knowledge, and as graduate students they often find it difficult to deal with the demands of a research degree program that requires them to critically evaluate what they learn, to challenge the old, and to develop "new" knowledge. Doctoral programs need to be able to evaluate an applicant's ability to think critically and learn independently, and programs must, as necessary, support further development of these competencies. Two of the most unambiguous indications of research capacity are (1) an applicant's having earned a research master's degree from a university where stringent quality-assurance mechanisms are in place to ensure that the degree was awarded primarily on the basis of the student's own work, and (2) senior (or significant) authorship of publications in the peer-reviewed literature. Some universities allow members of their academic and research staffs, and staff members from associated research institutions, to undertake the $\mathrm{PhD}$ by published work (Wilson, 2002). In these cases, the doctoral admissions assessment is based on the number, the quality, and the coherence of the applicant's publications as well as on the applicant's potential to make a scholarly contribution at the doctoral level. In some countries, however, relatively few research doctoral applicants have such experience, and even when they do, it can be challenging to evaluate that experience, particularly among international applicants to doctoral programs.

\section{Proficiency in English}

English is now the language of higher education; most of the literature and most research papers are written in English. ${ }^{5}$ Teaching in $\mathrm{PhD}$ programs is commonly undertaken in English, and the dissertation is also written in English. Even where PhD students write their dissertations in their national languages, English proficiency is essential to the ability to conduct a literature review. Consequently, fluency in the reading and writing of English is one of the prime competencies expected of applicants to doctoral programs in most countries, and English proficiency, not least among those who speak English as their first language, is an indispensable prerequisite of achieving membership in the community of researchers.

Nevertheless, according to Biggs (2003), “despite language prerequisites, many international students undoubtedly have language problems that need attention; you cannot learn if you are not fluent in the language medium of instruction." Halai (2008b), studying the first-year "doctoral experience" of four students admitted to 


\section{B. L. BERNSTEIN ET AL.}

the first cohort of $\mathrm{PhD}$ candidates at her own university in Pakistan, found that all four experienced the faculty as very demanding regarding expectations for the ability to read and write in English (which was these students' second or third language). And Singh (2004) has noted the difference between an eighteen-year-old student in India and an eighteen-year-old student in an English-speaking country: the latter is free to learn "more and more about other subjects, whereas in our country a student does not have that option" but is obliged to "learn how to operate in English," a process that "sets [the Indian student] back by a couple of years."

\section{Competencies Expected of Research PhD Graduates}

Doctoral programs are now called upon to do more than prepare students to conduct research. The education of competent researchers - that is, researchers who not only can conduct research but also can communicate and contextualize their work and provide leadership in addressing the problems and needs of their regions - is an essential element of the rationale for advancing doctoral education in developing countries.

\section{Technical and Contextual Intelligence}

The ability to make a contribution through original research rests on the knowledge and analytical intelligence needed to conceptualize, design, and implement a substantive original research project (see Terenzini, 1993; Australian Qualifications Framework Advisory Board, 2007; Quality Assurance Agency for Higher Education, 2008). Nevertheless, moving from conducting research studies to creating an impact requires skill in communicating research findings. Despite progress in this area, many doctoral graduates do not know how or where to communicate their findings, nor do they know how to overcome the barriers to effective communication with different types of audiences, ranging from laypersons to experts (Baram-Tsabari \& Lewenstein, 2013; Rowan, 2003). ${ }^{6}$

Also essential to researchers is "contextual intelligence" (Terenzini, 1993), meaning the ability to synthesize and integrate specific research into the context of existing knowledge. For example, the instructions to examiners of doctoral theses typically ask them to comment on a candidate's capacity to place his or her research in a broader theoretical, practical, policy, and, preferably, international context. This capacity, generally reflected in the "discussion and implications" sections of journal articles, gains researchers legitimacy, trust, and respect.

According to Halai (2008a), the capacity to contextualize research findings is usually less developed in doctoral graduates in developing countries than in the graduates of more mature doctoral programs, but in developing countries it is particularly important for doctoral graduates to be able to take leadership roles as contributors to the research-based knowledge relevant to their chosen careers. In the developing nations, where educational institutions and their graduates constitute the hope for economic growth, for development of infrastructure, and for reduction of 
poverty (Bloom, Canning, \& Chan, 2005), a fundamental need is to provide training for teachers and strengthen primary and secondary education. The importance of educating university faculty for the preparation of teachers cannot be overestimated: a top priority in the developing world is to provide graduate-level preparation to faculty in tertiary educational settings.

\section{Transferable Skills}

There is broad and increasing agreement that doctoral candidates should be trained in ways that include the development of transferable skills (that is, generic professional competencies that are equally applicable to all professional settings). Any discussion of transferable skills must be grounded in an understanding of the transformational shifts of recent decades. The knowledge society now demands skills of workers and leaders that are different from the skill sets of the past. ${ }^{7}$ Indeed, the transformation to a global knowledge economy has been accompanied by what is perhaps the most dramatic in a series of shifting expectations for doctoral graduates. In the knowledge economy, three categories of competencies have been considered key: (1) the ability to act autonomously, (2) the ability to use tools interactively, and (3) the ability to function in socially heterogeneous groups (see Rychen \& Salganik, 2001; OECD, 2002). In addition, competent performance in a global society has been considered to involve flexible adaptation of ever-changing technical, interpersonal, and methodological skills (lifelong learning).

A growing body of reports also lists desired characteristics of $\mathrm{PhD}$ graduates that extend beyond the generation and application of new knowledge (the two areas of professional competence most commonly associated with "stewards of the discipline," to cite a term coined by the Carnegie Initiative on the Doctorate; see Golde, 2006). For example, in a report on the groundbreaking "Re-envisioning the $\mathrm{PhD}$ " project in the United States, Nyquist (2002) summarizes the views of hundreds of stakeholders in doctoral education; the core competencies reported as being sought by employers and students alike include the following nonacademic ones:

- Commitment to a chosen career on the basis of an understanding of varied opportunities and paths

- Teaching competency, broadly construed

- Understanding of the diversity of students, the workforce, and the global economy

- Ability to assume, as a responsibility of leadership, the roles of mentor and scholar-citizen

- Understanding of ethical conduct in all roles

- Effective communication

- Ability to work in teams

- Ability to translate expertise for understanding by public audiences and policy makers

Likewise, in a 2006 national US survey of $\mathrm{PhD}$ recipients in the social sciences, Nerad, Rudd, Morrison, \& Picciano (2008) found that competencies like communication 


\section{B. L. BERNSTEIN ET AL.}

skills, working in teams, working in interdisciplinary contexts, and managing people and budgets were very important for the positions held by these graduates five or more years after earning their degrees. Nevertheless, when the respondents to the survey were asked to rate the quality of the preparation they had received for these nonanalytical competencies, they gave their doctoral programs very low ratings in these areas.

Kuijpers and Scheerens (2006), defining career competencies in terms of selfmanagement abilities or behaviors (that is, abilities or behaviors relevant to all careers, irrespective of the particular position or setting), identify five self-assessed behaviors and motives related to career development: (1) reflection on work-related capacities, (2) reflection on career-related motives, (3) work exploration (that is, the search for environments where work competencies can be deployed), (4) career control (planning and self-promotion), and (5) networking (building and maintaining career-relevant contacts). Dwyer, Millett, and Payne (2006) include creative problem solving and communicating with diverse colleagues and clients among the desirable skills.

Research Councils UK (RCUK), the strategic partnership of the United Kingdom's seven research councils, developed a comprehensive list of the skills to be acquired by $\mathrm{PhD}$ students. ${ }^{8}$ Thirty-six skills were identified, including seven having to do with personal effectiveness (willingness to learn, creativity/originality, open-mindedness, self-assessment, self-discipline, awareness of support, and self-reliance), three related to teams and/or networking (networking, working in teams, and acquiring feedback skills), and four pertaining to career management (professional development, career management, development of transferable skills, and ability to promote oneself). One level of each competency, with behavioral indicators, was defined for the skill level expected of a student completing a PhD in engineering and the physical sciences.

Since 1998, the government of Australia has required all Australian universities to provide statements of the attributes expected of graduates of all degree programs. For example, according to the University of Melbourne's statement, doctoral education at that institution seeks

to develop graduates who demonstrate academic leadership, increasing independence, creativity and innovation in their research [and to] encourage the acquisition of a wide range of advanced and transferable skills. In addition, professional doctoral studies provide advanced training designed to enhance professional knowledge in a specialist area.

The university expects its doctoral graduates to possess the following qualities and skills:

- Advanced ability to initiate research and formulate viable research questions

- Demonstrated capacity to design, conduct, and report sustained and original research 
- The capacity to contextualize research within an international corpus of specialist knowledge

- Advanced ability to evaluate and synthesize research-based and scholarly literature

- Advanced understanding of key disciplinary and multidisciplinary norms and perspectives relevant to the field

- Highly developed problem-solving abilities and flexibility of approach

- The ability to analyze critically within and across a changing disciplinary environment

- The capacity to disseminate the results of research and scholarship through oral and written communication to a variety of audiences

- The capacity to cooperate with and respect the contributions of fellow researchers and scholars

- Profound respect for truth and intellectual integrity, and for the ethics of research and scholarship

- Advanced facility in the management of information, including, where appropriate, the application of computer systems and software to the student's field of study

- An understanding of the relevance and value of their research to national and international communities of scholars and collaborators

- Awareness, where appropriate, of issues related to the management of intellectual property and the commercialization of innovation

- The ability to formulate applications to relevant agencies, such as funding bodies and ethics committees

\section{Understanding the Need for Transferable Skills}

The nature of preparing for, applying to, and graduating from a $\mathrm{PhD}$ program has changed dramatically over time. In addition, although the last two decades have seen an increase in the number of PhDs awarded, in some fields that increase has been accompanied by decreased demand for traditional researchers. Given these changes, it is important to understand why the need for training in transferable skills has come to exist, and how expansion of learning outcomes at the doctoral level may fundamentally change the way in which research doctoral programs are structured. ${ }^{9}$

In earlier years, $\mathrm{PhD}$ programs' intense focus on research training was intended to prepare research scholars and faculty for research universities (indeed, preparing scholars for the academy remains the focus of many departments). But new realities have led to calls for a broader agenda in doctoral education. According to Nerad et al. (2008), "PhD careers today demand competencies not traditionally acquired in $\mathrm{PhD}$ education." There is also growing recognition that what universities typically offer in graduate programs is different from what students actually expect and want. Golde and Dore (2001) go so far as to identify a "three-way mismatch . . . between the purpose of doctoral education, aspirations of the students, and the realities of their careers - within and outside academia." 10 


\section{B. L. BERNSTEIN ET AL.}

In many countries, the professional roles and settings embraced by today's doctoral graduates reach beyond the walls of the research university. These new roles - together with responsibility for providing leadership in various occupational settings, promoting innovation and competitiveness, and preparing future practitioners, leaders, and scholars - demand skill sets that extend far beyond those associated with cognition, analysis, technical applications, and research, the traditional competencies transmitted through doctoral education.

In addition, even though most individuals admitted to $\mathrm{PhD}$ programs in the major academic centers continue to aspire to university-based research careers, many students and graduates change their interests along the way, whereas still others are unable to secure the academic positions they had hoped to find. And in the United States, in some fields (for example, engineering and bioscience), even those PhDs who still aspire to academic careers have been taking academic positions outside research universities - a trend likely to continue, since current demographic changes in education will probably increase the need for qualified faculty in what are primarily teaching universities and colleges. ${ }^{11}$

Moreover, not only are doctoral graduates' initial career environments more diverse, there have also been marked changes in the form and typical progression of a $\mathrm{PhD}$ holder's career. Career paths in the modern and dynamic knowledge economy are influenced by greater vertical and horizontal mobility, by frequent variation in work tasks, and by individuals' free agency (Kuijpers \& Scheerens, 2006). Accordingly, many graduate schools in the United States and elsewhere offer seminars and programs intended to help $\mathrm{PhD}$ graduates become more versatile in meeting the demands of nonacademic work.

The international context of doctoral preparation, and of $\mathrm{PhD}$ graduates' mobility, offers additional impetus for broadening the conceptualization of world-class, globally literate doctoral-level preparation. As a consequence, some scholars, lamenting that doctoral programs produce graduates with narrow perspectives and skills, have called for expanding doctoral programs to include a "general education" (Stimpson, 2002) so as to create a better match between life and work in an increasingly complex, diverse, interconnected world.

The importance of developing an expanded skills agenda for doctoral education has been the focus of a series of reports and recommendations in the United States, the United Kingdom, Australia, and Canada, among other countries. For example, the three major research agencies in Canada organized a conference to discuss transferable skills, after which the Canadian Association for Graduate Studies produced a document on professional skills development for graduate students (Canadian Association for Graduate Studies, 2008).

In the United States, a report issued by the National Academy of Sciences (Committee on Science, Engineering, and Public Policy; National Academy of Sciences; National Academy of Engineering; \& Institute of Medicine, 1995) called for an improved version of $\mathrm{PhD}$ education, a mode that would "retain the existing strengths ... while substantially increasing the information available, the potential 
versatility of the students, and the career options afforded to them." As examples of crucial career skills, the report cited the ability to communicate complex ideas to nonspecialists and the ability to work well in teams. Another US-based report (Woodrow Wilson National Fellowship Foundation, 2005) implies that the purpose of doctoral education should be reframed as preparing the next generation of intellectual leaders, some of whom will become teacher-scholars while others become practitioners. In an introduction to a report on the Carnegie Initiative on the Doctorate, Shulman notes that the $\mathrm{PhD}$ "is a route to many destinations, and those holding the doctorate follow diverse career paths. Some seek out a life in academe, while others choose business or industry, or work in government or nonprofit settings. Yet all are scholars, for the work of scholarship is not a function of setting but of purpose and commitment. The profession of the scholar requires specialized, even esoteric knowledge. But it also entails a larger set of obligations and commitments that are not only intellectual but moral" (cited in Walker, Golde, Jones, Bueschel, \& Hutchings, 2008, p. 8).

In the United Kingdom, a recommendation (Roberts, 2002) for training in transferable skills was reinforced by the government in two key ways. First, expectations were established for new "threshold standards" to represent an essential minimum for high-quality doctoral research degree programs (Department for Employment and Learning, Northern Ireland; Higher Education Funding Council for England; Higher Education Funding Council for Wales; \& Scottish Higher Education Funding Council, 2003). Second, the UK Quality Assurance Agency Code of Practice for Research Degrees (Quality Assurance Agency for Higher Education, 2004) has based the requirement for documentation of transferable skills on the assertion that transferable skills are vital to graduates' ability to make a successful transition to employment and to assume personal long-term responsibility for managing their careers.

\section{Responding to the Need for Transferable Skills}

There is variety in the approaches that have been introduced for training in transferable skills. These approaches include formal, informal, and self-directed methods, but whatever form such preparation takes, it is deliberately designed to extend beyond the one-to-one apprenticeship that is the "signature pedagogy" (Shulman, 2005) associated with research doctorates (Walker et al., 2008). In France, for example, seminars called doctoriales offer doctoral students in the sciences opportunities to develop employability skills; weeklong seminar retreats are also available. With significant governmental funding, the UK Grad Programme and the Vitae organization into which it later evolved have provided exemplary and nationwide opportunities for graduate students in the United Kingdom to develop a wide array of transferable skills.

Also in the United Kingdom, as well as in Australia and the United States, many institutions have developed short courses or workshops on pertinent career-related topics. The University of Manchester, for instance, offers a series of workshops for 


\section{B. L. BERNSTEIN ET AL.}

research, and the university also offers graduate students instruction on topics that include networking, creating ideas, critical thinking, management, and starting a business. Training in nonacademic skills is generally optional for students in the United Kingdom, but the Quality Assurance Agency for Higher Education does require UK universities that award doctorates to offer a personal development plan that provides a means for students to increase and monitor their personal and professional skills, including skills for managing their careers, setting personal goals, and tracking their progress toward those goals. In the United States, an initiative to offer doctoral students training in personal, professional, and communication skills is under way at Arizona State University, where Bernstein and her colleagues have developed CareerWISE, a free Internet-delivered resource that provides individualized skill training and resources for building career resilience among women in science and engineering doctoral programs, the areas where women are most underrepresented (Bernstein, 2011). ${ }^{12}$

\section{Assessing Transferable Skills}

The establishment of learning objectives for core career competencies rests on the assumption that the achievement of these competencies will be assessed in some fashion. In many countries, substantial work has been done to create processes and requirements for evaluating doctoral degree programs. There has also been much recent work on identifying, operationalizing, and assessing the competencies needed for entering particular professions, such as teaching, engineering, and psychology (see, for example, Committee on International Relations in Psychology Task Force, 2009). Nevertheless, the literature is sparse with respect to graduate-level assessment of students' competencies (Maki \& Borkowski, 2006).

Amid increasing efforts to create opportunities for $\mathrm{PhD}$ students to learn transferable skills, the emerging challenge lies in developing ways to evaluate the effectiveness of such efforts. One issue identified by Shaw and Green (2002), who developed tentative benchmarks for the doctoral outcomes suggested in the United Kingdom (outcomes now codified in Quality Assurance Agency for Higher Education, 2008), is that it is much easier to develop credible benchmarks for those products of learning and research that can be assessed during the examination process than to develop benchmarks for process outcomes like time management, compliance with deadlines, facility with interpersonal and group interactions, motivation, tenacity, proactivity, independence, and autonomy - all transferable skills and qualities that are highly valued by employers, including universities. Notwithstanding that difficulty, it is important to evaluate both types of outcomes, whether the doctoral degree is obtained by research or coursework, and whether doctoral learning is applied in scholarly or practice settings. Another issue is that there has been virtually no scholarly attention to the assessment of transferable skills, apart from efforts based on self-ratings. ${ }^{13,14}$ The emerging practice of preparing a professional portfolio (Walker et al., 2008) to document knowledge and skills may be a promising approach in that construction of a portfolio to document transferable skills reinforces the intended relevant learning 
outcomes by making the student responsible for reflection, critical self-assessment, documentation, and self-presentation (Cyr \& Muth, 2006; Walker et al., 2008).

\section{EVALUATING THE OUTCOMES OF DOCTORAL EDUCATION}

The ability to evaluate the effectiveness of doctoral education rests on adequate assessment of individual learning. But it is also important to note that assessments of research productivity and learning outcomes at the doctoral level have value beyond determining students' readiness to graduate. Faculty, in bringing the habits of scholarly inquiry and evidence to their work with students, must have "difficult conversations" (Walker et al., 2008, p. 146) about the purposes and intended outcomes of a given program so that assessments of learning can provide evidence not only of whether students are meeting program goals but also of how those goals might be advanced more effectively. The previous section of this chapter addressed assessment in terms of the specific skills and characteristics that should be expected of today's research $\mathrm{PhD}$ applicants and graduates. This section considers possibilities for and approaches to evaluating the research doctorate itself as an educational outcome.

Although improvement in doctoral programs around the world continues to be an important concern (Council of Graduate Schools, 2010), processes for quality assurance and accreditation vary widely across countries. Similarly, despite general agreement on the desired fundamental outcomes of research doctoral education, countries vary considerably in their practices with respect to the awarding of a research doctorate. This is true in particular regarding the examination of the candidate's thesis or dissertation, the relative importance placed on the candidate's oral examination, and, in some contexts, requirements related to the candidate's publications in peer-reviewed literature.

Pressure to harmonize these practices, and to develop consensus on criteria against which the quality of a research doctorate can be benchmarked, has been increasing (in Australia and the United Kingdom, for example). Pressure will also come from the continued globalization of doctoral programs, both at the regional level (for instance, through the Bologna Process) and at the level of bilateral agreements developed between universities for conjoint doctoral enrollments (by way of such agreements as cotutelle arrangements).

\section{Examining the Thesis or Dissertation}

In most cases, the procedures for evaluating successful completion of a dissertation or thesis are defined by faculties, universities, or governments, but there is no consensus, not even by discipline, on the criteria for judging the quality of a dissertation (Walker et al., 2008). Mullins and Kiley (2002), for example, have found that even when universities specify the criteria for awarding the doctorate, experienced examiners tend not to rely on institutional criteria but rather on their own judgments of whether 


\section{B. L. BERNSTEIN ET AL.}

a thesis or dissertation meets the required standard. By contrast, inexperienced examiners pay more attention to institutional criteria but are unsure of where the boundaries lie with respect to characterizing a thesis or a dissertation as very good or poor, and they view their uncertainty as a major issue, especially if they have no familiarity with theses or dissertations other than their own (Kiley \& Mullins, 2004).

There are also marked differences in the examination process from one country to another. In the United States, examination of the dissertation is usually conducted by the candidate's dissertation committee, which may or may not include members external to the university. Elsewhere-for example, in Canada, in most European countries, and in the United Kingdom-the examiners include the candidate's supervisors as well as one or two external examiners (who typically also participate in the oral examination). In Australia, it is a governmental requirement for at least two independent external examiners to scrutinize a research doctoral thesis and make recommendations to a university thesis committee. Notably, some Australian universities also use internal examiners. Bourke, Holbrook, and Lovat (2006) found that all eight of the Australian universities in their sample permitted additional examiners, particularly when the primary examiners disagreed on their recommendations (in which case an additional examiner, usually external, might be asked to adjudicate the conflicting reports of the primary examiners or to provide an additional report on the thesis or dissertation itself).

\section{Conducting the Oral Examination}

In most European countries, in North America, and in New Zealand, a viva voce (oral examination of the candidate) is a mandatory component of the doctoral examination process. But there is considerable variation in how the viva voce is conducted. Procedures may include a public seminar presentation (followed by a closed session with the candidate's thesis committee) or a public oral defense of the thesis. In Australia, it is increasingly common for a university to require a research doctoral candidate to present an exit or precompletion seminar before submitting the thesis for examination.

Also in Australia, as well as in Brazil, India, Malaysia, and South Africa, the oral examination is optional rather than mandatory, and selection of this option is typically infrequent if the decision is left to the discretion of the candidate. In addition, some universities conduct an oral examination only in certain situationsto resolve dissonant reports from examiners, for example, or at the request of an examiner who has found a level of ambiguity in the candidate's thesis, or when an examiner questions the candidate's grasp of a particular issue.

\section{Requiring Peer-Reviewed Publications}

Countries also differ with respect to the requirement for published research to constitute one element of earning a doctorate. In the United Kingdom, for example, 
the doctoral learning outcomes specified by the Quality Assurance Agency for Higher Education (2008) suggest that the research submitted for the doctoral degree should merit publication, although UK universities have seldom if ever expected a $\mathrm{PhD}$ candidate to publish the results of doctoral research as a prerequisite of having the thesis examined (unless the candidate is undertaking the $\mathrm{PhD}$ by published work; see Wilson, 2002). By contrast, the life sciences department of at least one leading Chinese research university requires a $\mathrm{PhD}$ candidate to have at least two papers accepted for publication in Institute for Scientific Information journals before the candidate's thesis can be examined (Office of the President, Sun Yat-Sen University, Guangzhou, 2008). And in many European countries, such as the Netherlands and Denmark, the $\mathrm{PhD}$ candidate produces the thesis (which includes an integrated introduction and conclusion) as a publication or collection of publications brought out by the university from which the doctorate is sought.

Many universities now expect (or require) doctoral theses to be posted on the Internet for publication in e-repositories, or through national programs. ${ }^{15}$ The growing pressure for research $\mathrm{PhD}$ candidates to publish their doctoral research raises important questions about research conducted in a team context, as research is typically conducted in the laboratory sciences or in interdisciplinary collaborations: a research $\mathrm{PhD}$ candidate normally makes a declaration that the thesis is a product of his or her own research except as otherwise indicated, and yet candidates are increasingly required to describe, and even to quantify, their own contributions relative to those of other team members, who are listed as co-authors of the published research.

\section{CURRENT FORCES FOR CHANGE IN RESEARCH DOCTORAL EDUCATION}

The likely drivers of change in doctoral education over the next decades can be classified into three broad categories: (1) changes in the contexts and sites where research is conducted and where research training is delivered, (2) changes in how knowledge is produced, organized, distributed, and used, and (3) changes in the demographic makeup of those who are pursuing or will pursue the research doctorate.

\section{Research Contexts}

The single most important driver of change in doctoral education is arguably an economic one. For example, the enormous and rapidly escalating costs of "big science" mean that researchers, especially in universities, must forge new partnerships simply in order to gain access to the instrumentation and human capital necessary to sustain the research enterprise. Meanwhile, in the arts and humanities, the rapidly rising costs of scholarly publication, together with pressure on library budgets, are challenging notions of the doctoral dissertation as a monograph. It is clear that research and scholarship in all disciplines will rely on financial support from the governmental, academic, and private sectors and will increasingly involve team members who 


\section{B. L. BERNSTEIN ET AL.}

cross national and disciplinary boundaries. As a result-given the nature of these new partnerships, their costs, and growing awareness of the importance of research to national economies - more and more stakeholders are paying close attention to whether they are getting their money's worth. It is this reality, in large part, that underlies a recurring theme of this chapter: the importance of developing appropriate standards for evaluating the quality of the major doctoral research products (theses or dissertations) and for assessing the outcomes of programs designed to enhance the capacity of doctoral graduates to work in the interdisciplinary, multicultural, rapidly changing contexts characteristic of the twenty-first century.

If the knowledge economy and the costs of doing research are the distal forces driving changes in doctoral education, a more proximal driver is the geographic mobility of the scholarly labor force. The need to prepare a workforce of scientists and scholars who can work across national boundaries and in different settings, coupled with the great attention now being given to accountability and assessment, is generating increased attention to the desirability of developing a globally defined set of expected outcomes for doctoral learning.

The dissertation or thesis will almost certainly remain the essential artifact of doctoral education, although it continues to expand beyond its traditional written form (for example, by incorporating performances, digital works, and exhibitions). Nations will probably continue such practices as the use of a supervisory committee and the use of both an oral and a written defense of the thesis or dissertation, but demands for indicators of quality are likely to become more widespread. Employers in both the academic and the private sector will increasingly expect and demand a more transparent system so that they can better evaluate the credentials of the people they seek to employ across the global labor marketplace.

In a potentially transformational shift, competency-based approaches to delivering and documenting the outcomes of doctoral education are likely to become both more common and more sophisticated. As noted earlier, the conversation about this change in approach has already begun. There is general agreement, for example, that teamwork, communication skills, and intercultural or global awareness are important dimensions of doctoral preparation, and yet there is much less agreement about which additional competencies will characterize the most productive scholars and leaders of the coming century, or about how those future scholars and leaders might be best and most efficiently educated.

\section{Production and Distribution of Cutting-Edge Scholarship}

Just as forces external to the academy are driving change in the area of doctoral education, so too is the evolving nature of scholarship. For example, Ortega (2008) has speculated on a number of issues related to five core competencies that may become part and parcel of the twenty-first-century research doctorate: (1) competencies related to interdisciplinarity, (2) synthetic or inductive approaches to research, as the focus increasingly shifts away from deductive or analytical modes of scholarship 
and science, (3) the skills that doctoral graduates will need as innovation and design increasingly mark both cutting-edge basic research and the development of highend industries and products, (4) the cultural competencies needed for effective work in teams of individuals from diverse disciplinary, racial, ethnic, religious, or national backgrounds, and (5) the new analytical, interpersonal, and communication strategies that doctoral graduates will need in order to have rewarding careers as knowledge increasingly comes to be held not by individuals but by communities. Efforts to grapple with these issues at the level of the university, the nation, and the global environment will shape doctoral education significantly over the remainder of the twenty-first century, and perhaps beyond.

\section{Demographics of Doctoral Students}

Doctoral education is expanding rapidly. It is no longer limited to a handful of European or North American nations. In Asia and elsewhere, doctoral programs have increased not only in size but also in scholarly productivity. This trend will certainly continue and will lead by itself to increasing diversity in the backgrounds, learning styles, and career aspirations of doctoral students. As the demands of the knowledge economy increase the demand for lifelong learning, additional diversity will come from variability in the typical age of incoming doctoral students. And with these changes comes an opportunity: attention to the demographics of students in research doctoral programs offers a new avenue for considering experiences in such programs as well as the competencies that are outcomes of graduate study (see Anderson-Rowland, Bernstein, \& Russo, 2007).

The educational and career pathways that these students bring to their studies will vary, as will the career trajectories that they follow when they graduate from their doctoral programs. While they are enrolled in their programs, these students will demand the same high-level educational experience that has characterized graduate education in the past, but they will also insist on its being delivered in ways cognizant of the reality that not all learning occurs in carefully circumscribed blocks of time, either in a classroom or at the feet of a mentor.

In turn, the employers of tomorrow's students will ask us to certify that these doctoral graduates have not only all the strengths associated with more traditional recipients of the $\mathrm{PhD}$ but also many of the new skills and habits of mind identified in this chapter. Thus changes in the demographics of doctoral students will simply serve to reinforce the economic and scientific trends that are moving doctoral education toward embracing an approach increasingly based on competencies and learning outcomes.

\section{QUESTIONS FOR FURTHER RESEARCH}

The research doctorate has evolved and will continue to change as it addresses the needs of the research community, employers, society, and governmental funding 


\section{B. L. BERNSTEIN ET AL.}

agencies as well as private sponsors. In this chapter, we have examined in detail the academic and personal competencies that research doctoral graduates increasingly are expected to possess upon completion of the $\mathrm{PhD}$. We have also considered some of the many forces driving change in the sector of global doctoral education. Naturally, questions for further research are suggested by our examination of the evolution of the $\mathrm{PhD}$. These are questions about systems of doctoral education, about what those systems produce, and about outcomes for individual doctoral graduates.

To take just one example, the current and increasing flow of international students from developing countries to developed nations raises serious issues for systems of doctoral education in both settings. Students absorb the norms and values of the academic systems in which they study, and they often return home with a desire to transform their native countries' universities in such a way as to make them more closely resemble the institutions and programs where they studied abroad. But because they may seek to do this in ways that prove unrealistic and unattainable in the short term (Altbach, 2004), the question arises of how universities in the developing nations can build their doctoral programs quickly enough to capitalize on the enthusiasm of these returning scholars.

To take another example, as the agenda related to transferable skills gains strength in different systems, the challenge is to develop a common taxonomy and nomenclature for the transferable skills expected of new $\mathrm{PhD}$ graduates. It will also be necessary to develop tools, instruments, and processes for assessing transferable competencies. When it comes to transferable skills, should there be different expectations for learning outcomes at the undergraduate and doctoral levels? For example, will outcomes be measured at the level of the competency itself (that is, proficiency in as opposed to mastery of transferable skills), or are there some competencies in this area that should be expected only of doctoral graduates?

As yet another example, increased attention to outcomes, and to accountability for raising rates of degree completion, may well bring about new developments in the criteria for admission to doctoral programs and to programs of predoctoral preparation. For instance, in the first year of a PhD program there may be a more concerted effort to identify reliable predictors of the candidate's capacity for independent research and then to take a more serious approach to the hard decision about whether the candidate should continue in the program. In addition, the everexpanding roles and settings for doctoral graduates may hasten the development of tools for assessing the candidate's noncognitive skills at the time when he or she enters the program.

Today's $\mathrm{PhD}$ graduates can be found in academic, industrial, and governmental settings as well as in settings related to private practice and entrepreneurship, and they occupy a variety of roles - as researchers, teachers, administrators, policy makers, practitioners, executives, and consultants - in national contexts ranging from the sophisticated to the developing. Just as placements and roles for people at the doctoral level have expanded, so too have expectations regarding their skills 
and competencies. In view of these developments, it has become incumbent on faculties and institutions to embrace the new era and to shoulder the responsibility of preparing doctoral students for enduring success and global impact. Thus Nerad et al. (2008), having analyzed the results of their national survey of $\mathrm{PhD}$ graduates, call for faculty to recognize the fundamental paradigm shift in $\mathrm{PhD}$ education:

The $\mathrm{PhD}$ in the 21st century is preparation for employment ... . New times bring new needs. $\mathrm{PhD}$ programs should move out of the 19th and into the $21 \mathrm{st}$ century by bringing professional competencies from the margin to the center of doctoral education. ... [Preparation in these areas] should not be "added on" in generic courses, but should be an integral part of becoming an independent researcher in the student's $\mathrm{PhD}$ discipline.

It is now broadly understood that world-class $\mathrm{PhD}$ preparation must extend beyond academic, disciplinary, analytical, and technical knowledge and skills. Transferable skills are also an essential element of $\mathrm{PhD}$ education, and they provide the foundation for leadership so necessary in the global knowledge economy.

\section{NOTES}

1. In this chapter, we use the terms $P h D$, research $P h D$, and research doctorate synonymously. We recognize, however, that there are also professional doctoral degrees that have a different purpose and emphasize slightly different learning outcomes. The professional doctorate or named doctorate (these terms are not fully accepted or understood everywhere in the world) makes a significant and original contribution to policy and/or professional practice. By contrast, the research $\mathrm{PhD}$ makes a significant and original contribution to knowledge.

2. Bourke, Holbrook, and Lovat (2006) report that in their survey involving evaluation of and recommendations for the theses of $804 \mathrm{PhD}$ graduates from eight Australian universities, almost half the examiners were from outside the country. This approach was highly valued as a contribution to the international competitiveness of Australian PhD graduates. Significant differences were also found in the level of recommendations made by examiners from different countries. Most notably, in a comparison between examiners from Australia and examiners from the United States (the two largest cohorts), the US examiners' recommendations were much more favorable than those of the Australians.

3. Early in a program, candidates in the United States and Canada are assessed on their performance in advanced coursework as well as on written and sometimes oral examinations of their research knowledge in the context of their disciplines (these examinations are variously known as candidacy, comprehensive, cumulative, and preliminary examinations). In the US, the first year or a longer period is typically devoted to coursework, after which a comprehensive examination ensures not only that the coursework has been integrated but also that the $\mathrm{PhD}$ candidate has gained the ability to synthesize the varied components of the program. In South Asian countries such as Pakistan, despite the expectation of a master's degree for entry into a doctoral program, doctoral candidates are often underprepared in the content of their disciplines, and so most new doctoral programs in that country follow the US tradition. Many universities in the United Kingdom require a $\mathrm{PhD}$ candidate to register in an MPhil program initially, with progression to a $\mathrm{PhD}$ program typically involving the development of a satisfactory thesis outline and substantive written work in the field of the thesis. In most Australian universities, research doctoral candidates are now admitted on a provisional basis, where they remain until they successfully complete what is known as the confirmation of candidature, which typically involves the presentation of a research proposal, a proposal seminar, and substantive written work relevant to the proposed thesis, such as a literature review. In-progress research master's candidates 


\section{B. L. BERNSTEIN ET AL.}

may also be allowed to transfer to a doctoral program through this process, if they can demonstrate the viability of their work with respect to the likelihood of its fulfilling the desired doctoral outcomes.

4. Bourke et al. (2006) explored the relationship between, on the one hand, the quality of the theses submitted by $804 \mathrm{PhD}$ graduates from eight Australian universities and, on the other, the academic qualifications of those graduates when they embarked on doctoral study. These researchers rated thesis quality on the basis of the evaluative options chosen by discipline-relevant university committees, whose decisions were informed by the recommendations and written reports of mostly external examiners. The committees' available options were to accept a thesis without amendment, to accept it with minor corrections invited, to accept it subject to major correction, or not to accept it in its current form. Somewhat surprisingly, the researchers found that entry qualifications did not have a statistically significant effect on the measured quality of a graduate's $\mathrm{PhD}$ thesis, although entry qualifications did affect the time it took to submit the thesis. Candidates with honors bachelor's degrees took an average of 7.8 semesters to submit the thesis, compared with 7.2 semesters for candidates with research master's degrees and 6.8 semesters for other candidates (the study did not include cases in which a candidate failed to submit a thesis). This study's conclusions are germane to attempts to harmonize higher education across Europe through the Bologna Process.

5. Although there are notable exceptions, it is nevertheless the case that in developing countries such as Pakistan, India, Bangladesh, and Nepal, the colonial powers imposed their own languages on national systems of education, and the local languages have not been able to develop to the point where tertiary education can be undertaken in them (Singh, 2004; Isani \& Virk, 2003). In Pakistan, for instance, there are social science journals published in English, but not a single reputable research journal in the social sciences is published in Urdu, the national language. Even the website of Pakistan's Higher Education Commission is in English; see http://www.hec.gov.pk (retrieved November 13, 2013).

6. The oral examination, if it includes a public seminar, may be an important mechanism for measuring this capacity.

7. Miller (2003) offers the parameters of a learning-intensive society as the context for higher education. Tracing the evolution of patterns in learning intensity (that is, the content and flow of tacit and explicit knowledge) from early times to the present, Miller largely identifies agricultural society with the intensity of "know-how," industrial society with dependence on the higher intensity of "know-what," and the evolving knowledge economy (and the parallel learning society) with improved management of "know-what" along with a high intensity of "know-who" and "know-why."

8. That effort led to the development of the UK Grad Programme, which later became the Vitae organization, characterizing itself as "championing the personal, professional and career development of doctoral researchers and research staff in higher education institutions and research institutes"; see the Vitae website (http://www.vitae.ac.uk), retrieved November 13, 2013.

9. Ideally, of course, any restructuring that occurs will avoid compromising the quality of the research undertaken in a graduate program, or lowering the quality of the program itself.

10. As one example of this "mismatch," Gold and Dore (2001) found that more than half the doctoral students they surveyed wanted to perform community service, but only one in five felt prepared by graduate education to do so.

11. In the United States, the highly successful Preparing Future Faculty (PFF) program was spawned by the recognition that teaching in comprehensive universities, undergraduate institutions, and two-year community colleges draws on different sets of skills. The PFF program, now a common element among other university resources, expands disciplinary research preparation with an emphasis on teaching skills, exposure to varied types of higher education institutions and settings, and attention to the needs of undergraduate students; see the PFF website (http://preparing-faculty.org), retrieved November 13, 2013.

12. The CareerWISE project (http://careerwise.asu.edu) is supported by the National Science Foundation. Randomized clinical trials in the United States have revealed rigorous differences between the project's treatment participants and its wait-list control participants.

13. Bromley, Boran, and Myddelton (2007) constructed an instrument designed to tap self-assessed baseline skills for thirty-six competencies and to tailor activities for skill development. It is interesting to note that new doctoral students gave themselves high ratings on competencies associated with personal effectiveness but low ratings on competencies associated with career management. 


\section{THE CONTINUING EVOLUTION OF THE RESEARCH DOCTORATE}

14. Wilkins, Bernstein, Bekki, Harrison, \& Atkinson (2012) have developed an instrument that measures doctoral students' knowledge, application, and self-efficacy with respect to active listening skills in science and engineering contexts. Active listening, a component of interpersonal communication skills, has been found to be important to academic and career progress, particularly among women in male-dominated fields.

15. One example is the Australasian Digital Thesis Program, which publishes theses from Australia and New Zealand. Most universities in the United States require $\mathrm{PhD}$ candidates to submit their dissertations for publication and archiving by UMI Dissertation Publishing, a business unit of ProQuest. In Canada, research theses are deposited with Theses Canada, a section of Library and Archives Canada.

\section{REFERENCES}

Altbach, P. G. (2004). Higher education crosses borders. Change, 36, 18-25.

Anderson-Rowland, M. R., Bernstein, B. L., \& Russo, N. F. (2007, June 24-27). Encouragers and discouragers for domestic and international women in doctoral programs in engineering and computer science. Paper presented at annual conference of the American Society for Engineering Education, Honolulu.

Australian Qualifications Framework Advisory Board. (2007). AQF implementation handbook (4th ed.). Carlton (Melbourne), Australia: Australian Qualifications Framework Advisory Board.

Baram-Tsabari, A., \& Lewenstein, B. V. (2013). An instrument for assessing scientists' written skills in public communication of science. Science Communication, 35(1), 56-85.

Bernstein, B. L. (2011). Managing barriers and building supports in science and engineering doctoral programs: Conceptual underpinnings for a new online training program for women. Journal of Women and Minorities in Science and Engineering, 17(1), 29-50.

Biggs, J. (2003). Teaching for quality learning at university: What the student does (2nd ed.). Buckingham: Society for Research into Higher Education \& Open University Press.

Bloom, D., Canning, D., \& Chan, K. (2005). Higher education and economic development in Africa. Report commissioned by Africa Region Human Development (AFTHD), World Bank. Washington, DC: World Bank.

Bourke, S., Holbrook, A., \& Lovat, T. (2006, November 27-30). Relationships of PhD candidate, candidature and examination characteristics with thesis outcomes. Paper presented at annual conference of the Australian Association for Research in Education, Adelaide.

Bromley, A. P., Boran, J. R., \& Myddelton, W. A. (2007). Investigating the baseline skills of research students using a competency-based self-assessment method. Active Learning in Higher Education, $8(2), 117-37$.

Canadian Association for Graduate Studies. (2008). Professional skills development for graduate students. Ottawa: Canadian Association for Graduate Studies.

Committee on International Relations in Psychology Task Force. (2009). APA's role in international quality assurance: APA as a learning partner. Washington, DC: Committee on International Relations in Psychology Task Force, Board of Education Affairs, American Psychological Association. Retrieved November 12, 2013, from http://www.apa.org/international/governance/cirp/qa-report-2008.pdf

Committee on Science, Engineering, and Public Policy; National Academy of Sciences; National Academy of Engineering; \& Institute of Medicine. (1995). Reshaping the graduate education of scientists and engineers. Washington, DC: National Academy Press.

Council of Graduate Schools. (2010, September 13-15). Principles and practices for assessing the quality of (post)graduate education and research training. Presentation at the Strategic Leaders Global Summit, Brisbane, Australia. Retrieved November 12, 2013, from http://www.cgsnet.org/ckfinder/ userfiles/files/Principles_and_Practices_Brisbane_2010.pdf

Cyr, T., \& Muth, R. (2006). Portfolios in doctoral education. In P. L. Maki \& N. A. Borkowski (Eds.), The assessment of doctoral education: Emerging criteria and new models for improving outcomes. Sterling, VA: Stylus Publishing. 


\section{B. L. BERNSTEIN ET AL.}

Department for Employment and Learning, Northern Ireland; Higher Education Funding Council for England; Higher Education Funding Council for Wales; \& Scottish Higher Education Funding Council. (2003). Improving standards in postgraduate research degree programs: A report to the higher education funding councils of England, Scotland and Wales. London, UK: Higher Education Funding Council for England. Retrieved November 12, 2013, from http://www.hefce.ac.uk/pubs/ hefce/2003/03 23.htm

Dwyer, C. A., Millett, C. M., \& Payne, D. G. (2006). A culture of evidence: Postsecondary assessment and learning outcomes: Recommendations to policymakers and the higher education community. Princeton, NJ: Educational Testing Service.

European University Association. (2005). Doctoral programmes for the European knowledge society: Report on the EUA Doctoral programmes project, 2004-2005. Brussels: European University Association.

European University Association. (2006, December 7-9). Matching ambition with responsibilities and resources: Final conclusions-Preparing recommendations for the London Communiqué. Report on Bologna Seminar on Doctoral Programmes, Nice. Retrieved November 12, 2013, from http://www. ehea.info/Uploads/Seminars/NICE_ConclusionsRecommendations_.pdf

European University Association. (2007, October 11-12). Doctoral programmes in Europe: Access, recruitment and admission. Report of the EUA Workshop, Brussels. Retrieved November 12, 2013, from http://www.eua.be/fileadmin/user_upload/files/Doctoral_workshop_Brussels/Workshop_ doctoral_programmes_Report.pdf

Golde, C. M. (2006). Preparing stewards of the discipline. In C. M. Golde \& G. E. Walker (Eds.), Envisioning the future of doctoral education: Preparing stewards of the discipline. San Francisco, CA: Jossey-Bass.

Golde, C. M., \& Dore, T. M. (2001). At cross purposes: What the experiences of today's doctoral students reveal about doctoral education. Survey initiated by the Pew Charitable Trusts. Philadelphia: Pew Charitable Trusts. Retrieved November 12, 2013, from http://www.phd-survey.org/report\%20final. pdf

Halai, N. (2008a, December 16). A look at globalization and internationalization of doctoral education. Keynote presentation at University of Sains Malaysia 3rd International Conference on Postgraduate Education, Penang.

Halai, N. (2008b, May 24-26). What does it mean to be a doctoral student? Creating new identities. Paper presented at annual conference of the Association for Institutional Research, Seattle.

Isani, U. A. G., \& Virk, M. L. (2003). Higher education in Pakistan : A historical and futuristic perspective. Islamabad: National Book Foundation.

Kiley, M., \& Mullins, G. (2004). Examining the examiners: How inexperienced examiners approach the assessment of research theses. International Journal of Educational Research, 41, 121-135.

Kuijpers, M. A., \& Scheerens, J. (2006). Career competencies for the modern career. Journal of Career Development, 32, 303-319.

Maki, P. L., \& Borkowski, N. A. (Eds.). (2006). The assessment of doctoral education: Emerging criteria and new models for improving outcomes. Sterling, VA: Stylus Publishing.

Miller, R. (2003, December 11-12). The future of the tertiary education sector: Scenarios for a learning society. Paper presented at OECD/Japanese seminar on the future of universities, Tokyo. Retrieved November 12, 2013, from www.mext.go.jp/a_menu/kokusai/forum/04022701/004/001.pdf

Mullins, G., \& Kiley, M. (2002). It's a PhD, not a Nobel Prize: How experienced examiners assess research theses. Studies in Higher Education, 27(4), 369-386.

Nerad, M., Rudd, E., Morrison, E., \& Picciano, J. (2008). Social science PhDs-Five+ years out: A national survey of PhDs in six fields. Highlights report. Seattle: Center for Innovation and Research in Graduate Education, University of Washington.

Nyquist, J. (2002). The PhD: A tapestry of change for the 21st century. Change: The Magazine of Higher Learning, 34(6), 12-20.

OECD [Organisation for Economic Co-operation and Development]. (2002). Definition and selection of competencies: Theoretical and conceptual foundations. Paris: OECD. 


\section{THE CONTINUING EVOLUTION OF THE RESEARCH DOCTORATE}

Office of the President, Sun Yat-Sen University, Guangzhou. (2008). Specific provisions for Ph.D. students (in Chinese). Retrieved May 21, 2012, from http://xxgk.sysu.edu.cn/ml $/ \mathrm{ml} 04 / 73652 . h t m$

Ortega, S. T. (2008). Priority issues that call for discussion. In Council of Graduate Schools in the United States, Global perspectives on graduate education: Proceedings of the strategic leaders global summit on graduate education. Washington, DC: Council of Graduate Schools.

Quality Assurance Agency for Higher Education. (2004). Code of practice for the assurance of academic quality and standards in higher education, sec. 1: Postgraduate research programmes. Gloucester: Quality Assurance Agency for Higher Education. Retrieved November 12, 2013, from http://www. qaa.ac.uk/Publications/InformationAndGuidance/Documents/postgrad2004.pdf

Quality Assurance Agency for Higher Education. (2008). The framework for higher education qualifications in England, Wales and Northern Ireland. Gloucester: Quality Assurance Agency for Higher Education.

Roberts, G. (2002). SET for success: The supply of people with science, technology, engineering and mathematics skills. Report submitted to the Chancellor of the Exchequer. London, UK: HM Treasury.

Rowan, K. E. (2003). Informing and explaining skills: Theory and research on informative communication. In J. O. Greene \& B. R. Burleson (Eds.), Handbook of communication and social interaction skills. Mahwah, NJ: Lawrence Erlbaum.

Rychen, D. S., \& Salganik, L. H. (Eds.). (2001). Defining and selecting key competencies. Göttingen: Hogrefe \& Huber.

Shaw, M., \& Green, D. H. (2002). Benchmarking the PhD: A tentative beginning. Quality Assurance in Education, 10(2), 116-124.

Shulman, L. S. (2005). Signature pedagogies in the professions. Daedalus, 134(3), 52-59.

Singh, A. (2004). Fifty years of higher education in India: The role of the University Grants Commission. New Delhi, IN: Sage.

Stimpson, C. R. (2002, November 1). General education for graduate education. Chronicle of Higher Education.

Task Force on Higher Education and Society. (2000). Higher education in developing countries: Peril and promise. Washington, DC: Task Force on Higher Education and Society, World Bank.

Terenzini, P. T. (1993). On the nature of institutional research and the knowledge and skills it requires. Research in Higher Education, 34, 1-10.

Walker, G. E., Golde, C. M., Jones, L., Bueschel, A. C., \& Hutchings, P. (2008). The formation of scholars: Rethinking doctoral education for the twenty-first century. San Francisco, CA: Jossey-Bass.

Wandering scholars. (2005, September 8). The Economist. Retrieved November 12, 2013, from http:// www.economist.com/node/4340017

Wilkins, K. G., Bernstein, B. L., Bekki, J. M., Harrison, C. J., \& Atkinson, R. K. (2012, October 3-6). Development of the Science, Technology, Engineering, and Mathematics Communication Skills Assessment (STEM-CSA). Presentation at 42nd annual Frontiers in Education Conference, Seattle.

Wilson, K. (2002). Quality assurance issues for a $\mathrm{PhD}$ by published work: A case study. Quality Assurance in Education, 10(2), 71-78.

Woodrow Wilson National Fellowship Foundation. (2005). The responsive PhD: Innovations in U.S. doctoral education. Princeton, NJ: Woodrow Wilson National Fellowship Foundation.

\section{ADDITIONAL SOURCES}

Altbach, P. G. (2007). Tradition and transition: The international imperative in higher education. Rotterdam, NL: Sense Publishers.

Altbach, P. G., Reisberg, L., \& Rumbley, L. E. (Eds.). (2009, July 5-8). Trends in global higher education: Tracking an academic revolution. Report presented at United Nations Educational, Scientific and Cultural Organization (UNESCO) world conference on higher education, Paris.

Christensen, K. K. (2005, February 3-5). General rapporteur's report. Presented at the Bologna Seminar on Doctoral Programmes for the European Knowledge Society, Salzburg. 


\section{B. L. BERNSTEIN ET AL.}

Commission on Institutions of Higher Education. (2011). Standards for accreditation (rev. ed.). Bedford, MA: Commission on Institutions of Higher Education, New England Association of Schools and Colleges. Retrieved November 12, 2013, from http://cihe.neasc.org/standards_policies/standards

Committee of Vice-Chancellors and Principals. (1996). Review of postgraduate education. London, UK: Committee of Vice-Chancellors and Principals, Standing Conference of Principals, Higher Education Funding Council for England. Retrieved November 12, 2013, from http://www.hefce.ac.uk/Pubs/ hefce/1996/m14_96.htm

European University Association. (2007). Doctoral programmes in Europe's universities: Report prepared for European universities and ministers of higher education. Brussels: European University Association.

Ostriker, J. P., Kuh, C. V., \& Voytuk, J. A. (Eds.); Committee to Assess Research-Doctorate Programs; \& National Research Council. (2011). A data-based assessment of research doctorate programs in the United States. Washington, DC: National Academies Press.

Pink, D. (2006). A whole new mind: Moving from the Information Age to the Conceptual Age. New York, NY: Penguin.

Research Councils UK \& Arts and Humanities Research Board. (2002). Skills training requirements for research students: Joint statement by the Research Councils/AHRB. In J. Metcalfe, Q. Thompson, \& H. Green (Eds.), Improving standards in postgraduate research degree programmes: A report to the higher education funding councils of England, Scotland and Wales. London, UK: Higher Education Funding Council for England. 